
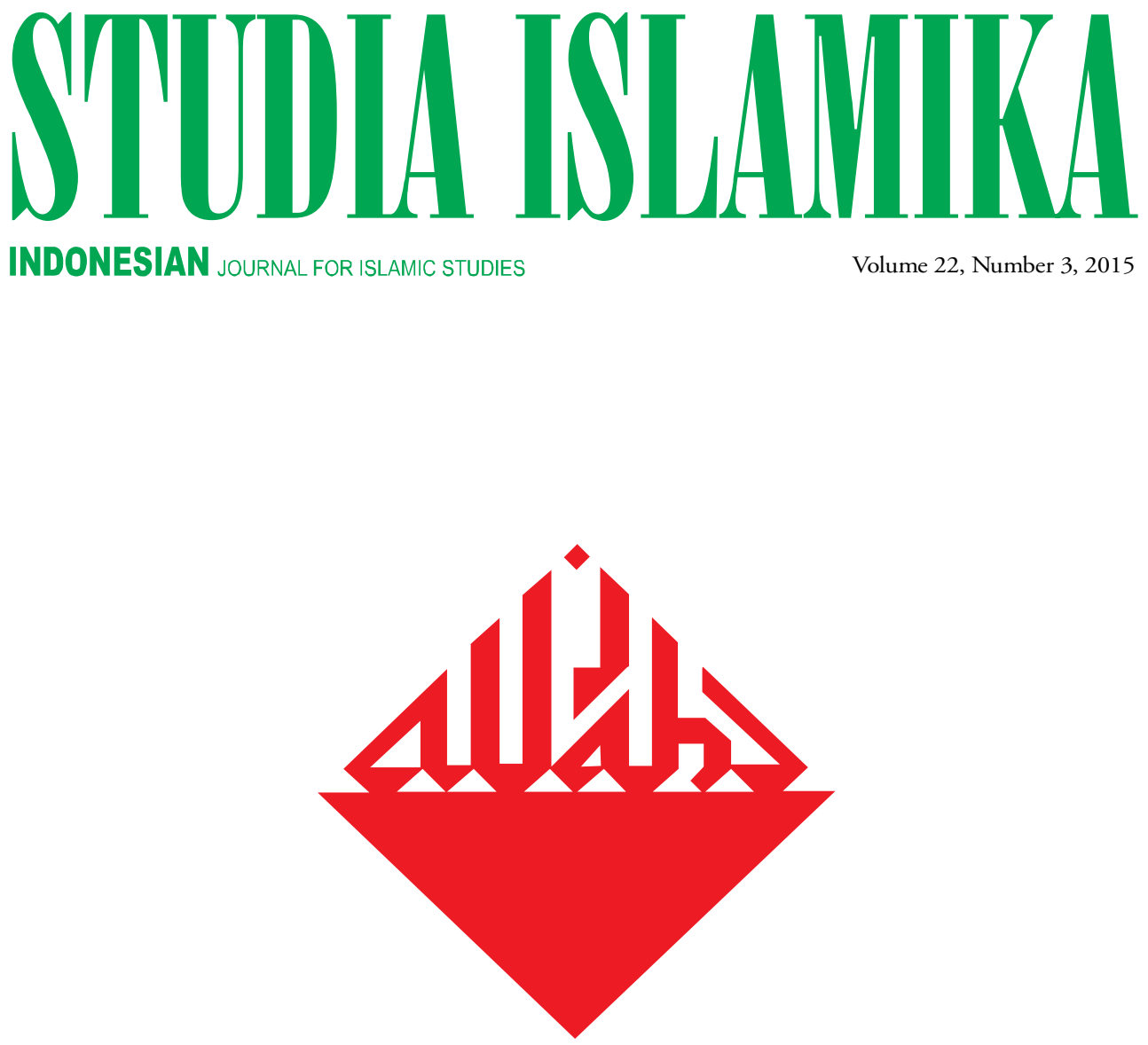

Religious Pluralism or Conformity in Southeast Asia’s Cultural Legacy

Anthony Reid

Marketing IsLam

THROUGH ZAKaT INSTITUTIONS IN INDONESIA

Asep Saepudin Jahar

The Register of the Qadi Court

“KiYahi PËQIh Najmuddin" of the Sultanate

of BANTĚN, I754-I756 CE.

Ayang Utriza Yakin 
SIIIDIA ISLAMIIIKA 



\section{STIDIA ISLAVIIIKA}

Indonesian Journal for Islamic Studies

Vol. 22, no. 3, 2015

EDITOR-IN-CHIEF

Azyumardi Azra

MANAGING EDITOR

Ayang Utriza Yakin

EDITORS

Saiful Mujani

Jamhari

Jajat Burhanudin

Oman Fathurahman

Fuad Jabali

Ali Munhanif

Saiful Umam

Ismatu Ropi

Dadi Darmadi

Didin Syafruddin

Jajang Jahroni

Din Wahid

INTERNATIONAL EDITORIAL BOARD

M. Quraish Shihab (Syarif Hidayatullah State Islamic University of Jakarta, INDONESIA)

Taufik Abdullah (Indonesian Institute of Sciences (LIPI), INDONESIA)

Nur A. Fadhil Lubis (State Islamic University of Sumatera Utara, INDONESIA)

M.C. Ricklefs (Australian National University, AUSTRALIA)

Martin van Bruinessen (Utrecht University, NETHERLANDS)

John R. Bowen (Washington University, USA)

M. Kamal Hasan (International Islamic University, MALAYSIA)

Virginia M. Hooker (Australian National University, AUSTRALIA)

Edwin P. Wieringa (Universität zu Köln, GERMANY)

Robert W. Hefner (Boston University, USA)

Rémy Madinier (Centre national de la recherche scientifique (CNRS), FRANCE)

R. Michael Feener (National University of Singapore, SINGAPORE)

Michael F. Laffan (Princeton University, USA)

\section{ASSISTANT TO THE EDITORS}

Testriono

Muhammad Nida' Fadlan

ENGLISH LANGUAGE ADVISOR

Shirley Baker

Simon Gladman

ARABIC LANGUAGE ADVISOR

Nursamad

Tb. Ade Asnawi

COVER DESIGNER

S. Prinka 
STUDIA ISLAMIKA (ISSN 0215-0492; E-ISSN: 2355-6145) is an international journal published by the Center for the Study of Islam and Society (PPIM) Syarif Hidayatullah State Islamic University of Jakarta, INDONESIA. It specializes in Indonesian Islamic studies in particular, and Southeast Asian Islamic studies in general, and is intended to communicate original researches and current issues on the subject. This journal warmly welcomes contributions from scholars of related disciplines. All submitted papers are subject to double-blind review process.

STUDIA ISLAMIKA has been accredited by The Ministry of Education and Culture, Republic of Indonesia as an academic journal (SK Dirjen Dikti No. 56/DIKTI/Kep/2012).

STUDIA ISLAMIKA has become a CrossRef Member since year 2014. Therefore, all articles published by STUDIA ISLAMIKA will have unique Digital Object Identifier (DOI) number.

STUDIA ISLAMIKA is indexed in Scopus since 30 May 2015.

(C) Copyright Reserved

Editorial Office:

STUDIA ISLAMIKA, Gedung Pusat Pengkajian Islam dan Masyarakat (PPIM) UIN Jakarta,

Jl. Kertamukti No. 5, Pisangan Barat, Cirendeu, Ciputat 15419, Jakarta, Indonesia.

Phone: (62-21) 7423543, 7499272, Fax: (62-21) 7408633;

E-mail: studia.islamika@uinjkt.ac.id

Website: http://journal.uinjkt.ac.id/index.php/studia-islamika

Annual subscription rates from outside Indonesia, institution: US $\$ 75,00$ and the cost of a single copy is US\$25,00; individual: US\$ 50,00 and the cost of a single copy is US\$ 20,00 . Rates do not include international postage and handling.

Please make all payment through bank transfer to: PPIM, Bank Mandiri KCP Tangerang Graha Karnos, Indonesia, account No. 101-00-0514550-1 (USD),

\section{Swift Code: bmriidja}

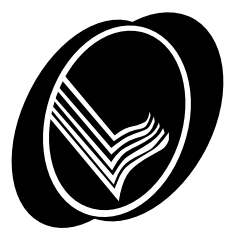

Harga berlangganan di Indonesia untuk satu tahun, lembaga: Rp. 150.000,-, harga satu edisi Rp. 50.000,-; individu: Rp. 100.000,-, harga satu edisi Rp. 40.000,-. Harga belum termasuk ongkos kirim.

Pembayaran melalui PPIM, Bank Mandiri KCP Tangerang Graha Karnos, No. Rek: 128-00-0105080-3 


\section{Table of Contents}

\section{Articles}

387 Anthony Reid

Religious Pluralism or Conformity in Southeast Asia's Cultural Legacy

405 Asep Saepudin Jahar

Marketing Islam

through Zakat Institutions in Indonesia

443 Ayang Utriza Yakin

The Register of the Qadi Court

"Kiyahi Péqih Najmuddin" of the Sultanate of Bantěn, 1754-1756 CE.

487 Yahya Mohamed Abmed Ghaleb

Ishkālīyāt al-Intimā’ al-Wațanī

'inda al-Muhājirīn al-Hadạāimah fī Indūnīsīyā

fì al-Niṣf al-Awwal min al-Qarn al-'Ishrīn

535 Aan Hasanah

Al-Qiyam al-Thaqāfīyah wa Țābi' al-Sha ‘b

li Jayl al-Muslimīn al-Shubbān al-Indūnīsīyīn

\section{Book Review}

563 Testriono

Islam Indonesia dan Demokratisasi:

Dari Transisi ke Konsolidasi 

Anthony Reid

\title{
Religious Pluralism or Conformity in Southeast Asia's Cultural Legacy
}

\begin{abstract}
In a recently published book, the present author argues that Asia is "the great laboratory of religious pluralism." The jostling together of mosques, viharas, churches and all kinds of temples has long been a feature of the vibrant cities of Southeast Asia, while anthropologists have celebrated the diversity of its rural people. Yet there is a paradox. At the level of formal religious adherence, Southeast Asia looks to be one of the world's least diverse regions. This article addresses both the deeper sources of religious tolerance and the modern factors tending, notably in Indonesia, to replace that pattern with one of greater religious conformity. The Indonesian state motto is the epitome of this paradox -Bhinneka Tunggal Ika, 'They are many, yet they are one.' The article concludes that while the older tolerance of diversity is indeed under threat today, Southeast Asia's own traditions should prove a valuable supplement to modern human rights concepts in maintaining the balance.
\end{abstract}

Keywords: Pluralism, Religion, Conformity, Mysticism, Tolerance. 
Abstrak: Dalam bukunya yang terbaru, penulis artikel ini menjelaskan bahwa Asia adalah "laboratorium besar untuk pluralisme agama." Keberdampingan antara masjid, vihara, gereja, dan berbagai jenis tempat ibadah sudah sejak lama menjadi ciri khas kota-kota Asia Tenggara yang dinamis, sementara para antropolog memuji keragaman masyarakat pedesaannya. Kendati demikian, terdapat paradoks. Pada tingkat anutan agama formal, Asia Tenggara tampak seperti salah satu wilayah dengan tingkat keragaman paling rendah di dunia. Tulisan ini menunjukkan sumber-sumber terpenting tentang toleransi beragama dan faktor-faktormodernyang cenderung, terutama di Indonesia, menggantikan pola tersebut dengan salah satu penyesuaian keagamaan yang lebih besar. Semboyan negara Indonesia, yaitu Bhinneka Tunggal Ika, yang bermakna 'berbeda-beda, tetapi tetap satu jua' adalah lambang dari paradoks tersebut. Penulis menyimpulkan bahwa ketika dewasa ini toleransi kemajemukan yang lama semakin terancam, maka tradisi-tradisi Asia Tenggara itu sendiriseharusnya menunjukkan dukungan yang penting bagi konsep Hak Asasi Manusia modern dalam hal menjaga keseimbangan tersebut.

Kata kunci: Kemajemukan, Agama, Kesesuaian, Mistisisme, Toleransi.

$$
\begin{aligned}
& \text { ملخص: في كتبه الصادرة حديثا، بين كاتب هذه المقالة أن آسيا هي 》المختبر }
\end{aligned}
$$

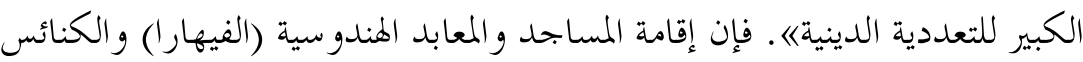

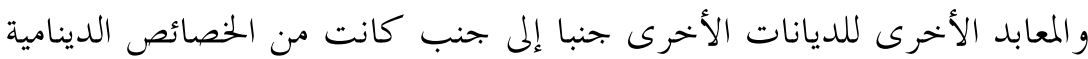

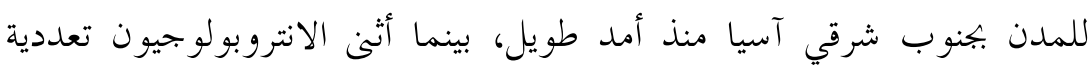

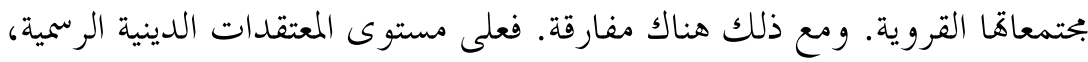

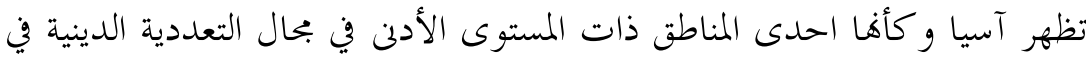

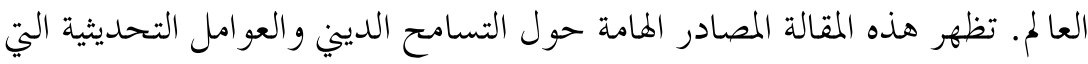

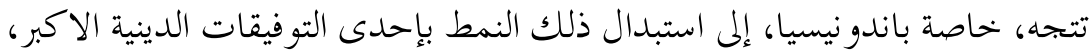

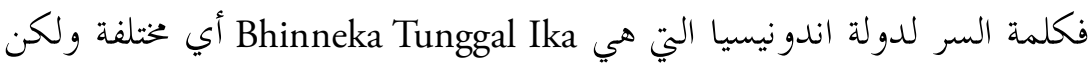

$$
\begin{aligned}
& \text { مع ذلك لا تزال واحدة هي عباة عن تلك المقارقة. أنا توصلت إلى نتيجة هي أنه إنه }
\end{aligned}
$$

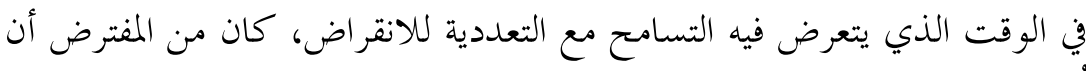

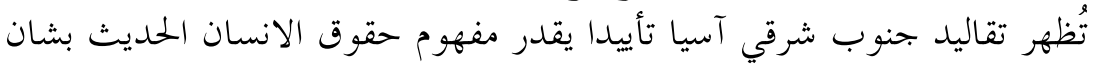

$$
\begin{aligned}
& \text { الحفاظ على ذلك التوازن. }
\end{aligned}
$$$$
\text { الكلمات المفتاحية: التعددية، الدين، التوافق، التصوف، التسامح. }
$$ 
$\mathrm{I}$ argued in a recent book that Asia was "the great laboratory of religious pluralism", and sought to deny historical legitimacy to religious exclusivism in either southern Asia or the very different strong-state regimes of northeast Asia. It was the somewhat peculiar combination of religion and power in the West, I argued, that introduced ideas of exclusivist religious orthodoxy, whether in its mediaeval Christian or Muslim form (Reid 2014; Reid and Gilsenan 2008, 1).

Furthermore, the humid tropics including Southeast Asia were and are peculiarly resistant towards homogenising political structures of any kind. Much more than elsewhere in Eurasia, these high-rainfall areas have permitted the survival of stateless, animist hunter-gatherers and swidden farmers in the hills even while modern cosmopolitan cities flourish on the plains. We find an extraordinary abundance of languages, modes of production, cultures and belief patterns continuing to coexist in close proximity, in contrast with the relative cultural uniformity that strong states, print and modern media have established in China, Japan, Europe, North America and Russia. Fieldworkers continue to report "the enormous religious diversity" of the highlands of Southeast Asia (Scott 2010, 156), and in particular the "profound religious heterogeneity” of Indonesia (Schiller 1996, 409).

So how would I explain two seemingly quite contrary phenomena? Firstly, Southeast Asian countries appear in statistical terms to be more homogeneous that the original heartlands of their religions in the Middle East and India. More than $80 \%$ of the populations of Indonesia (86\%); the Philippines (80\%), Thailand (94\%), Burma (89\%) and Cambodia (92\%) today formally subscribe not just to a single religion, but to a single school of that religion: Sunni Islam of the Shafi'i legal school (madhhab) in Indonesia, Roman Catholic Christianity of the Latin rite in the Philippines, and Buddhism of the Theravada School in the Mainland countries. Although Malaysia looks statistically more diverse, it is the least tolerant of Asian states towards its majority population, legally allowing no Malay at all to be other than a Sunni Muslim.

Secondly, Asia's $21^{\text {st }}$ century has so far appeared to be marked by unprecedented violence inspired by religion, in contrast to the nationalism that dominated the bloodshed of the $20^{\text {th }}$. We don't need to be reminded of the Bali bombings, church-burnings, atrocities in the southern Philippines, outright Muslim-Christian battles in eastern 
Indonesia and Muslim-Buddhist ones in South Thailand and Myanmar. The recent brutality against Muslims in Arakan (Myanmar) and against the inoffensive Ahmadiyya minority in Indonesia highlights what seems a surprising intolerance of difference.

Was I wrong-headed and absurdly overoptimistic in the book mentioned above? Or is it that the celebrated tolerance of countries such as Indonesia, Malaysia and Thailand is a thing of the past, of only historical interest, no more able to resist nationalism, group solidarity and religious exclusiveness in modern guise than could Europe before it?

\section{The Fundamental Sources of Diversity}

The revealed 'religions of the book' brought exclusivist ideas to Asia, but in the past they adjusted to Asian realities. Not only did the Muslim rulers of India learn to govern a majority Hindu population in peace; but the Europeans learned from them how to rule over a still greater diversity of subjects on the basis of a still smaller minority of alien Christians.

This Asian pattern of diversity still seems to me more fundamental than the contrary trends towards exclusivism, so I will set out first the factors that seem to have sustained a tolerance of diversity in the long term. Let me begin with two more superficial or instrumental factors, and end with the two that are more profound but problematic.

\section{Pragmatic Considerations of Imperial World-Rulers}

In what Lieberman $(2003,2009)$ calls the "Exposed Zone" at the centre of the great Eurasian continent, including India and China, imperial world-conquerors periodically arose to establish their rule over a variety of peoples and faiths. The greatest of them, who intended not just to plunder but to rule long-term, often rose above any particular religion to declare themselves protectors of all faiths. The most ancient such case was Cyrus the Great of Persia (576-529 BCE), whose famous cylinder decreed that "each man would be free to worship his own gods", in contrast with the tyrannical attempts at suppression by some of his predecessors. This manifestation of what I called the "Asian" religious pattern of pluralism was repeated by many subsequent Asian conquerors, notably Alexander the Great, Genghis Khan and Queen Victoria. This theme may be less relevant to the past of Southeast Asia, one of Victor Lieberman's "protected zones", like Europe, beyond the 
reach of world-conquering nomads before the European maritime empires (Lieberman 2003, 92-117). But even in a world of nationstates and democracy, we should remember that our current task is to establish rules that will work for an entire interconnected planet. It was not inappropriate that the cylinder of Cyrus the Great was in 1971 canonized by the United Nations as a kind of founding charter of universal religious rights. ${ }^{1}$

The giant modern nation-states that succeeded the state-building emperors in Asia - notably China from the Manchus, India from the Mughals and then the British, Burma also from the British and Indonesia from the Dutch — did not fragment into relatively homogeneous religious or linguistic groups, as in Europe, but sought to retain imperial boundaries with all their diversity (Reid 2010a). Hence this ancient imperial idea remains relevant in Asia.

\section{Animist Experimentation}

A second factor was once fundamental to Southeast Asia's readiness to accept diversity, but is less convincing today. I mean the highly pragmatic and experimental ways in which the spirit world is viewed in rituals of healing, exorcism, fertility and so forth. As observed both by early European travellers and modern anthropologists, "if one man is richer than another they say it is because he must have sponsored the correct rituals at the right time" (Miles 1966, 5). Geertz also observed the readiness with which his informants would abandon one religious hypothesis for another which appeared to deliver better results in the material world. This underlying pragmatic assumption that whatever appears to work is worth emulating has had much to do, of course, with the acceptance by Southeast Asians of world religions associated with rich and powerful outsiders. There is no doubt in my mind that this very pragmatic approach to religious matters is still important in parts of Southeast Asia where dogmatic religion is least established, both in harmonious combination with formal adherence to such religions and in defiance of them. Traditional, private, often female diversities of belief and practice are tolerated in the name of adat, while the borrowed concept of religion (agama, sasana) has defined a more modern and male exclusivist public space (Kipp and Siregar 1987, 3-4). In modern cities with educated populations, however, this factor no longer operates to moderate exclusivist tendencies. 


\section{Open Societies Need to Tolerate Diversity}

On their arrival in Asia's highly plural cities Europeans were frequently astonished to discover mosques, temples, viharas and churches coexisting cheek by jowl. European Christians were not at that stage in the habit of tolerating even one another where they had control: Protestants were banned from Portuguese Melaka and Spanish Manila just as Catholics were from Dutch Batavia or Makassar. They were astonished by the pattern they encountered in Ayutthaya, where "a great multitude of strangers of different nations...settled there with the liberty of living according to their own customs, and of publicly exercising their several ways of worship" (La Loubère 1969, 112). The Siamese ruler famously told the Jesuits who sought his conversion to Christianity that God Himself appeared less concerned than the French that everyone should have the same belief about Him. "Ought not one to think that the true God takes as great pleasure to be honoured by different worships and ceremonies, as to be glorified by a prodigious number of creatures?" (cited Reid 1993, 192). In Banten each religious community celebrated its own festivals publicly to the delight of the general populace. In Patani the population was almost equally divided between Muslims, Buddhists and Chinese religionists, but each group was "very different in belief...not of one mind but of various sects" (van Neck 2013).

Port-states were particularly prominent in Southeast Asia, and more so as the maritime route between East and West Eurasia replaced the "silk road" in importance from the $13^{\text {th }}$ Century. Maritime cities such as the shifting ports of Sriwijaya and Champa, and later Melaka, Patani, Ayutthaya, Banten, Makassar and so forth, were highly dependent on the revenues of trade. The model Malay ruler was, as the Hikayat Hang Tuah $(1964,6)$ put it, "exceedingly kind and courteous, and ...cared for all foreigners," so that his reputation would attract foreign traders from everywhere. It was this pattern that convinced Dutch and English port-rulers that the indispensable key to success in Southeast Asia was to allow various kinds of Chinese, Muslims, Hindus and others to live and trade according to their own lights.

The story of $17^{\text {th }}$ century Aceh is particularly interesting for our theme, because the tension between the essential cosmopolitanism of the port and the religious exclusivism of some of its rivals was played out dramatically there. The most powerful of Aceh's rulers externally, 
Iskandar Muda (r.1607-36) was also the most autocratic internally. $\mathrm{He}$ appointed as Shaykh al-Islamm the very capable local scholar Shams alDīn al-Sumatranī (d. 1630), who with fluent Arabic acted as a mediator with foreigners as well as chief Islamic jurist. This sultan patronized Shams al-Dīn's mystical monism (wujüdìyah), but retained absolute power in religious as well as secular domains, and brooked no criticism of his un-Islamic lifestyle. When he died in 1636, evidently after killing his own son, there was a reaction under his son-in-law, Sultan Iskandar Thānī (1637-41), a captured Malay prince of Pahang who followed the stern dictates of the Gujarat-born Hadhrami scholar, Nūr al-Dīn al-Rānīrī.

al-Rānīrī had left Aceh earlier after quarrelling with Shams al-Dīn and his followers, but returned in May 1637 to become the chief Islamic advisor to Sultan Iskandar Thānī. He persuaded the sultan to have the books of the much loved Sumatran writers Hamzah Fanșūri and Shams al-Din burned in a public ceremony in front of the great mosque. Kamāl al-Dīn al-Jāwī, the previous Islamic advisor to the king, and other disciples of Shams al-Dīn who refused to renounce their views, were decapitated (Laffan 2009). The hard and narrow line extended to dealing with the foreign trader lifeblood of Aceh. Perhaps also under al-Rānīrì's guidance, the sultan excluded Chinese traders from Aceh because of their pork-eating habits, and instead of dealing with a Portuguese mission intended to restore relations with Aceh, he put to death all of them who did not accept conversion to Islam.

When Sultan Iskandar Thānī died after only a 4-year reign, this unpopular foreign-inspired exclusivism was again quickly repudiated, since it was ruinous for the welfare of the city. There were protests in the streets against the unpopular Rānīrī, and support for those who had been executed. A student of Kamāl al-Dīn named Sayf al-Rijāl returned to the city in August 1643 to confront Rānīrī. The merchant aristocrats (orang kaya) had chosen as the new sultan a woman, the widow of the hard-line sultan but daughter of his autocratic but pluralist predecessor. As perhaps was hoped, she declined to interfere in the dispute between the two Islamic camps, since as a woman she had no authority in the matter. She left the matter to the influential merchant-aristocrats who backed the more popular Sayf, and al-Rānīrī had to leave Aceh for his own safety. Chinese and Portuguese traders returned, the Catholics even found it the most congenial centre in the Archipelago after the 
Protestant Dutch had suppressed them elsewhere (Meersman 1967, 129-130; 133-134), and Banda Aceh became again a plural place where commerce was paramount. The Sufi Shaykh who provided the healing synthesis for Muslims was another local-born scholar, Aceh's beloved Syiah Kuala, 'Abd al-Ra'ūf al-Sinkilī. He sought to reconcile commitment to Shafi'i religious law with an appreciation of the fundamental unities taught by the Sufis. He also obtained a judgment from his teacher in Mecca, al-Kurānī, that it was a "grave error" to have executed those of a different opinion when they held that their position had not been understood (Azra 2004, 6-61; Nieuwenhuijze 1945, 200; Reid 2010b, 461-462; Wormser 2012, 41-45).

This dramatic contest played out in $17^{\text {th }}$ century Aceh was between a powerful minority (mostly foreign-born) who sought to impose their definition of orthodoxy by force and a majority who saw that Aceh could not flourish economically (let alone intellectually and spiritually) if it ceased to be a plural and open place. The victory of the latter was not permanent, and exclusivism has renewed its challenge in times such as our own. Yet the fundamental logic remains that Southeast Asia is a natural crossroads of the world, and can only flourish economically, intellectually and spiritually by embracing the diversity that comes with that, rather than fleeing from it.

\section{An Indic Assumption of Inner Unity, or "Non-Duality",} Animating the Diversity of Surface Phenomena

We have already noted this kind of monism within the Muslim sufi tradition that made Islam attractive to many Southeast Asians before the $17^{\text {th }}$ century. It goes much further back in time, and is best documented in Java, though much more widely influential. The most striking demonstration is the close proximity in both place and date of construction ( $8^{\text {th }} / 9^{\text {th }}$ centuries) of Buddhist Borobudur and Hindu Loro Jonggrang near Prambanan. Although scholars long hypothesized that these must have been built by two rival kingdoms, Sailendras and Sanjayas, it is increasingly clear that these and other monuments represented "a carefully maintained balance" between the two religions, competitive but complementary (Kim 2007, 14). Later there is a literary record that makes this theme explicit. The $14^{\text {th }}$ century Buddhist monk and poet Mpu Tantular celebrated not only the way of Buddha, but also the other two crucial elements of the kingdom's inherent balance 
- the priests of Shiva and the hermits of the indigenous tradition of ascetics (resi) (Hunter 2007). It became a theme of Javanese mysticism that different ritual paths to enlightenment such as those of Buddha and Shiva were only external expressions of an inner oneness. The state motto of contemporary Indonesia derives from a fourteenth century mystical poem, the Sutasoma, in which Mpu Tantular pondered the essential oneness beneath surface differences, including the new, still marginal presence of Islam: "the truth of Jina (Buddha) and the truth of Shiva are one; they are indeed different, but they remain one [Bhinneka Tunggal Ika], as there is no duality in Truth" (Santoso 1975, 578).

The deeper origin of this pattern was the Indic concept of religion centred on sacred sites and ritual practices rather than the definition of boundaries and orthodoxies. One writer on modern Hinduism described the "shocked incomprehension" of pre-modern Indians towards "the passion for dogmatic certainty" of some of their Muslim and Christian conquerors (Zaehner 1962, 4). The Rig Veda had famously declared that "The Absolute is one, although the sages have given it different names" (Madan 2005, 67), so that different cults could co-exist with each other and with Jainism, Sikhism, Islam and Zoroastrianism in India, or with Buddhism and animism in Southeast Asia. There were no such definitions of orthodoxy as the Muslim Shahadah or the Christian Nicene Creed. The great Muslim pioneer of comparative religion, Abū Rayhān al-Bīrūnī (973-1048), made a similar point after travelling northern India with the armies of Mahmud of Ghazni in the 1020s. "With regard to God, the Indians believe that he is one, eternal, without beginning and end, ... beyond all likeness and unlikeness, and neither resembling anything nor having anything resemble him.....On the whole there is very little disputing about theological topics among them; at the utmost, they fight with words, but they will never stake their soul or body or their property on religious controversy" (al-Bīrūnī 1030/1910).

Merle Ricklefs' Mystic Synthesis describes the way in which the Javanese variant of this world-view could be married to Islam, in such a way that one text referred to Javanese literature as the left eye, for viewing the self, and Arabic as the right eye, for viewing God. The key Muslim boundary-markers of not eating pork, modest dress and simple burials after death were accepted, and the Muslim identity passionately insisted upon, but the mystic continued to find his meaning in doctrines 
of non-duality (Ricklefs 2006, 222-228). This synthesis did not long outlast Sultan Agung's definition of it, but was particularly seriously challenged in the $19^{\text {th }}$ and $20^{\text {th }}$ centuries, as Ricklefs' two later books $(2007,2012)$ abundantly demonstrate.

In $20^{\text {th }}$ century Indonesia it often seemed that the dichotomy between "modernists" organised in Muhammadiyah and "Javanese traditionalists" organised in NU was a guarantor of pluralism even into the modern era. The latter had internalised enough of the mystic synthesis to resist Muhammadiyah attacks on long-established Javanese culture. This made it clear to Indonesians, in contrast for example to Malaysians, that there could not be a single or monolithic view of what Islam required (Soedjatmoko 1967). This healthy institutionalization of plurality has continued into the $21^{\text {st }}$ century debate around Islam Nusantara, but may have been eroded by less tolerant breakaways from both these $20^{\text {th }}$ century movements, as well as the factors discussed below.

The argument that Southeast Asian Islam was more likely to manage tolerance and diversity than other areas of the ummah has always rested primarily on the special case of Java. The most effective statement of the case that Javanese society is better able than most to handle diversity without resort to violence was Benedict Anderson's Mythology and the Tolerance of the Javanese (1965). This argued that the values of the shadow puppet theatre (wayang kulit), with its complex exploration of the interplay of good and evil in each of the much-loved but profoundly different characters of the stories, were the best guarantee that Javanese society would resist the siren calls to arms of divisive nationalism, militant Islam, communism and so forth. Unfortunately this was published in 1965, only a few months before the paroxysm of violence that resulted in the deaths of some half-million Javanese leftists. This in turn was explained by some experienced Java-watchers in terms of the wayang, and notably the cataclysmic Bharatayudha war which duty requires the god-heroes to undertake even though they know its disastrous outcome.

\section{Modern Pressures for Exclusive Conformity}

While the four factors above describe a past pattern which was relatively favourable to religious diversity, they do not tell the whole story, and particularly not for the last half-century. The forces making 
for homogeneity and a lessening of tolerance in our times might also be categorised under four headings: the state, nationalism, weakly institutionalised divisions and the global media.

\section{The State Uses Foreign Models to Build Its Legitimacy}

Like James Scott, I have been arguing for some time that states have been less important in Southeast Asian history than in most parts of the world, and less than the historians have assumed (Reid 1998a, 1998b, 2015). I don't dispute the argument of Lieberman $(2003,2009)$ that the state has been in general on the rise since the $15^{\text {th }}$ century, but insist that until the great $20^{\text {th }}$ century transformation it was less prominent than religion and popular culture as an integrator of Southeast Asian society. Its periods of expansion have consistently ridden on the back of homogenization in the religious field.

Precolonial kings, especially those newly wealthy through the "Age of Commerce", had a habit of embracing externally validated orthodoxy or orthopraxy as a way of arming themselves with a new kind of legitimacy that could undercut the local legitimacies of every lineage and sacred place. Tai and Mon kings in the $15^{\text {th }}$ century sent missions of monks to Sri Lanka to bring back Mahavihara rites of ordination that they then insisted were the only legitimate ones, thereby turning the new sangha into an instrument of unification they could control (Lieberman 2003, 43-44; 430-431; Reid 1993, 195). In the Archipelago, the port-states rising on the back of trade and its new weapons - Aceh, Banten, Demak, Melaka, Banjarmasin, Makassar, Ternate - could use the new religion, Islam, as their justification for overriding the traditional autonomies of their neighbours, as well as dynastic claims by older states. South Sulawesi is the case of Islamization we know best, because it occurred later than most in the first decade of the $17^{\text {th }}$ century when there are numerous sources about it. South Sulawesi had been a region where regional particularity had been intense, strengthened by supernatural sanctions and solemn agreements before the gods. But three years after becoming officially Muslim in 1607, Makassar was able to declare war on its neighbouring Bugis states, claiming loyalty to a higher imperative.

Southeast Asian rulers who accepted the new external faiths in this way (as opposed to foreign adventurers, also sometimes a factor), had no wish to lose to religious experts their role as mediators between the 
supernatural and the world of men. This indeed was often the key aspect of their power. It explains why there were no successful Christian kings; once they and their subjects discovered that a largely European clergy claimed the sole authority in the sacramental business of mediating with God, Christianity lost whatever charm it had for kings. Successful Southeast Asian kings managed to combine patronage of a unifying religion with their own sacral authority. The most powerful Majapahit king, Hayam Wuruk in the $14^{\text {th }}$ century, managed to be both "Shiva and Buddha, embodied in both the material and the immaterial", according to his court poet (Robson 1995, 25). Sultan Agung in the $17^{\text {th }}$ century was "respected as a God" by his Javanese, in the view of a visiting Dutch observer, even though he had established his brand of Javanised Islam as the indispensable and unifying belief system of the Javanese (van Goens 1956: 263).

Because Southeast Asia was a new frontier in the $16^{\text {th }}$ century for Theravada Buddhism, Islam and Christianity, these doctrines could spread in partnership with the rising state, rather than offering intractable pre-existing divisions to the state as in the Middle East and India. There is for example plenty of evidence of Shi' ite influence in the early Islamicate culture of Southeast Asia, most recently surveyed in the Singapore conference on 'Alid Piety' (Formichi and Feener 2015). But overt Shi'ís are today a tiny and endangered minority, and Southeast Asia is at a formal level the most uniform bastion anywhere of Sunni orthodoxy and Shafii law. The former is explained by the way a succession of rulers in the Malay world sought legitimation from centres of Sunni authority - essentially Mecca and Istanbul. The Shafi'i predominance is more difficult to explain, but has primarily to do with the influence of particular Hadhrami and Kurdish scholars of Shafi'i law in Indian Ocean networks, and the patronage of such networks by the same Sunni rulers.

Finally, we must explain the kind of contemporary state Islam that contributed to the appearance of homogeneity today. Many older mosques were built by communities, often with very different backgrounds and beliefs, and particularly so in the high colonial era when states had neither mandate nor political interest to build mosques. In the 1920s and up through the 1960s Muhammadiyah and NU members, for example, would not worship in each other's mosques, and the sense of Islam being plural was palpable. ${ }^{2}$ Since about 
1970, however, Malaysia, Indonesia and Brunei have built numerous spectacular mosques with state funds, greatly strengthening an official version of what Islam is. The teaching of Islam in state schools produced a lowest common denominator version of belief. A new unification of Islam has developed in Indonesia under Soeharto largely through the Ministry of Religion, and in Malaysia under Dr Mahathir. This state patronage of Islam, while helping to resolve some internal tensions, has served to "ring-fence" it (Mohamad 2010), stressing the boundaries of Islam and what all Muslims must have in common. A side effect appears to have been to make the Muslim community in these two countries less tolerant of personal autonomy and of internal religious pluralism.

\section{Anti-Imperial Nationalism Homogenizes Religious Identity}

If colonialism served to halt the progress of state patronage of Islam in Indonesia and Malaysia for half a century before 1942, it had the opposite effect on nationalism. Looking at the history of nationalism in Europe and the Middle East, one can readily see how nationalism flourished in partnership with one side or the other of the splits between Catholic and Protestant, and Sunni and Shi'a. English and Dutch nation-forming in the $16^{\text {th }}$ century were intrinsically linked to the emerging state's embracing of a new Protestant identity, while the nationalism of Ireland, Poland and Belgium at a later period entrenched a relatively defensive and ring-fenced understanding of Catholicism against the dominant Protestant (or Orthodox) oppressors. Iran's embrace of Shi'ism ensured that it would survive as a distinct brand, inextricably tied to that nationalism.

In Southeast Asia the dominant form of nationalism in the $20^{\text {th }}$ Century was the anti-Imperial type, which classically sought the unity of what Sukarno called the kaum sini [us here] against the kaum sana [them there] (Reid 2010a, 8-10; 28-30). Sarekat Islam in Indonesia, and the Young Men's Buddhist Association in Burma, mobilised people around the majority religion before the idea of secular nationalism was understood. In general, however, anti-imperial nationalism went further in the 1930s, to embrace Christian, Hindu and other minorities in the broadest possible front. Only in Thailand, where anti-imperial nationalism was not a persuasive option, did the religious element become a necessary central feature of the nationalist triad - 
king, nation/race, religion. In its most extreme form during the 1940s, Phibun Songkhram encouraged moves against Christian, Muslim and Chinese minorities with a ferocity not usually associated with the "land of smiles" (Strate 2011).

Overall, one might conclude that the complex relationship of majority religion and anti-imperial nationalism probably favoured religious neutrality more powerfully than it exploited anti-minority feelings, and the worst excesses occurred in the name of other forms of nationalism.

\section{Internal Divisions are Weakly Institutionalised}

In comparison with the situation in older centres of competitive Abrahamic (or revealed) religion, religious fault lines in Southeast Asia remain weakly institutionalised, largely as a result of the religious frontier phenomenon. The older forms of spirit worship, shamanism, and inner-directed kebatinan with an Indic flavour, have in general not been institutionalised as modern competitors with Islam and Christianity. The exceptions prove the rule: Balinese Hinduism became a shelter for Dayak Kaharingan and a few other traditionalists of the old religion, just because it made the fewest institutional or doctrinal demands (Schiller 1996). The old beliefs survive in the private domain, as women's business, and in Indonesia as ill-defined adat (custom). Although Islam and Buddhism cover a huge variety of beliefs and practices on the ground, not even such relatively coherent sub-cultures as the waktu telu of Lombok are recognised by the modern and official sector. Folk Catholicism in the Philippines, on the post-reformation model of institutional fragmentation, made more room for a highly institutionalised Iglesia ni Cristo.

There are therefore no congenial precedents for Ahmadiyya being recognised as a separate Muslim community.

\section{Totalizing Movements are Associated with Decontextualised Global Media}

As already clear from the first of these four factors, the appeal to an external "pure" model of belief, valid on a decontextualised cosmic scale, has been a factor in religious change for a very long time. If there is an absolute revealed truth, it must be valid everywhere. Modern communications have however speeded up the process, and in one sense greatly increased the necessity for a universally valid truth. Since 
young Southeast Asians are so much more readily in touch with the rest of the world than their grandparents, they are apt to reject their grandparents' local accommodations in favour of what appears a more global answer. This helps explain the simple-minded violence of Bali bombings, church burnings and Ahmadiyya bashings.

But globalised communications also have the opposite effect, of making people aware of the extraordinary diversity of belief in our one planet. The grasping at an exclusive simple truth is reassuring for some, including some very noisy and violent minorities, but there are surely more who find legitimation for difference in the hugely expanded choices available on the internet.

\section{Conclusion}

Have these factors making for homogeneity expunged the more fundamental sources of tolerance? Clearly not wholly, and not finally. Let me conclude merely by saying that Asia is not likely for a long time to be either secular in the European sense, where institutionalized religion is part of the culture but no longer practiced or believed by the majority, nor to have a sharp separation of Church and State in the US sense, whereby those of strong religious commitment can agree on not using the state to push their agendas. It therefore has need of its own sources of legitimating difference, and this paper has argued that it has them in abundance. But some aspects of modernity, including Max Weber's idea of 'rationalizing religion', can and do lead to greater demands for conformity to a single, simple code. We cannot imagine that we are already in a safe place in regard to religious violence and intolerance, and cannot rule out further tragic coalescences of group solidarity around religious exclusivity. 


\section{Endnotes}

1. The text has been variously translated, and essentially states that the conqueror has restored the gods to their respective temples, after his vanquished predecessor had sought to impose religious uniformity. A translation by Leo Oppenheim is included in Pritchard 1950.

2. I owe this point, and much of this paragraph, to a useful conversation with Greg Fealy in April 2011.

\section{Bibliography}

Anderson, Benedict R. O'G. 1965. Mythology and the Tolerance of the Javanese. Ithaca, N.Y.: Modern Indonesia Project, Southeast Asia Program, Dept. of Asian Studies, Cornell University.

Azra, Azyumardi. 2004. The Origins of Islamic Reformism in Southeast Asia: Networks of Malay-Indonesian and Middle Eastern 'Ulamā in the Seventeenth and Eighteenth Centuries. Crows' Nest, NSW: Allen \& Unwin; Honolulu: University of Hawai'i Press.

Formichi, Chiara, and Michael Feener, eds. 2015. Shiism In South East Asia: Alid Piety and Sectarian Constructions. Oxford University Press.

van Goens, Rijklof. 1956. "De samenvattend geschriften." In De vijf gezantschapsreizen van Rijklof van Goens naar het hof van Mataram, 16481654, ed. Hermanus Johannes de Graaf. M. Nijhoff.

Hunter, Thomas M. 2007. "The Body of the King: Reappraising Singhasari Period Syncretism." Journal of Southeast Asian Studies 38(1): 27-53.

Kassim, Ahmad, ed. 1964. Hikayat Hang Tuah. Kuala Lumpur: Dewan Bahasa dan Pustaka, Kementerian Pelajaran Malaysia.

Kim, Bokyung. 2007. "Politics, Religions, and Arts: The Relationship between Borobudur and Loro Jonggrong in Central Java (Indonesia).” Dissertation, UCLA.

Kipp, Rita Smith, and Susan Rodgers Siregar, eds. 1987. Indonesian Religions in Transition. University of Arizona Press.

Laffan, Michael. 2009. "When Is a Jawi Jawi? A Short Note on Pieter Sourij's 'Maldin' and His Minang Student 'Sayf Al-Rijal."' In Lost Times and Untold Tales from the Malay World, eds. Jan van der Putten and Mary Kilcline Cody. Singapore: NUS Press.

Lieberman, Victor. 2003. Strange Parallels: Volume 1, Integration on the Mainland: Southeast Asia in Global Context, c.800-1830. Cambridge: Cambridge University Press. 
2009. Strange Parallels: Volume 2, Mainland Mirrors: Europe, Japan, China, South Asia, and the Islands: Southeast Asia in Global Context, C.8001830. Cambridge: Cambridge University Press.

La Loubère, Simon de. 1969. A New Historical Relation of the Kingdom of Siam. Kuala Lumpur: Oxford University Press.

Madan, T.N. 2005. "Religions of India: Plurality and Pluralism." In Religious Pluralism in South Asia and Europe, eds. Jamal Malik and Helmut Reifeld. New Delhi: Oxford University Press.

Meersman, Achilles. 1967. The Franciscans in the Indonesian Archipelago, 13001775. Louvain: Nauwelaerts.

Miles, Douglas. 1966. "Shamanism and the Conversion of Ngadju Dayaks." Oceania 37(1): 1-12.

Mohamad, Maznah. 2010. "Making Majority, Undoing Family: Law, Religion and the Islamization of the State in Malaysia." Economy and Society 39(3): 360-84.

van Neck, Jacob. 2013. Ghosts of the Past in Southern Thailand: Essays on the History and Historiography of Patani. ed. Patrick Jory. trans. Anthony Reid. Singapore: NUS Press. pp. 22-30.

Nieuwenhuijze, CAO. 1945. "Samsu'l-Din van Pasai." Dissertation. Leiden University.

Pritchard, James Bennett. 1950. Ancient Near Eastern Texts: Relating to the Old Testament. Princeton Universty Press.

Reid, Anthony. 1993. Southeast Asia in the Age of Commerce, 1450-1680: Expansion and Crisis. Yale University Press.

. 1998a. "Inside-Out: The Colonial Displacement of Sumatra's Population." In Paper Landscapes: Essays in the Environmental History of Indonesia, eds. Peter Boomgaard, Freek Columbijn, and David Henley. Leiden: KITLV Press.

1998b. "Political 'tradition' in Indonesia: The One and the Many." Asian Studies Review 22(1): 23-38.

- 2010a. Imperial Alchemy: Nationalism and Political Identity in Southeast Asia. Cambridge: Cambridge University Press.

2010b. "Islam in Southeast Asia and the Indian Ocean Littoral, 15001800: Expansion, Polarization, Synthesis." In The New Cambridge History of Islam, Vol. 3: The Eastern Islamic World, Eleventh to Eighteenth Centuries, Cambridge: Cambridge University Press.

2014. "Religious Pluralism as an Asian Tradition." In Dealing with Diversity: Religion, Globalization, Violence, Gender and Disaster in Indonesia, ed. Bernard Adeney-Risakotta. Geneva, Yogyakarta: Globethnics.net, Indonesian 
Consortium for Religious Studies, 47. 2015. A History of Southeast Asia: Critical Crossroads. Oxford \& New York: John Wiley \& Sons.

Reid, Anthony, and Michael Gilsenan, eds. 2008. Islamic Legitimacy in a Plural Asia. Abingdon: Routledge.

Ricklefs, M.C. 2006. Mystic Synthesis in Java: A History of Islamization from the Fourteenth to the Early Nineteenth Centuries. Norwalk: EastBridge.

- 2007. Polarising Javanese Society: Islamic and Other Visions, C. 18301930. NUS Press.

- 2012. Islamisation and Its Opponents in Java: A Political, Social, Cultural and Religious History, C. 1930 to the Present. Singapore: NUS Press.

Robson, Stuart, ed. 1995. Desawarnana (Nagarakrtagama), by Mpu Prapanca. Leiden: KITLV Press.

Santoso, Soewito. 1975. Sutasoma, A Study in Old Javanese Wajrayana. New Delhi: International Academy of Indian Culture.

Schiller, Anne. 1996. "An 'Old' Religion in 'New Order' Indonesia: Notes on Ethnicity and Religious Affiliation." Sociology of Religion 57(4): 409-17.

Scott, James C. 2010. The Art of Not Being Governed: An Anarchist History of Upland Southeast Asia. New Haven: Yale University Press.

Strate, Shane. 2011. "An Uncivil State of Affairs: Fascism and Anti-Catholicism in Thailand, 1940-1944." Journal of Southeast Asian Studies 42(01): 59-87.

Wormser, Paul. 2012. Le Bustan Al-Salatin de Nuruddin Ar-Raniri: Reflexions Sur Le Rôle Culturel D'un étranger Dans Le Monde Malais Au XVIIe Siècle. Paris: Cahier d'Archipel.

Zaehner, Robert Charles. 1962. 12 Hinduism. London: Oxford University Press.

Anthony Reid, Australian National University, Canberra, Australia. Email: anthony.reid@anu.edu.au. 
Indexes

Studia Islamika: 2015

\section{Volume 22, Number 1, 2015}

1. M. A. Kevin Brice, Si Bule Masuk Islam: Western Converts to Islam in Indonesia - more than just Converts of Convenience?

2. Ahmad Suaedy \& Muhammad Hafiz, Citizenship Challenges in Myanmar's Democratic Transition: Case Study of the Rohingya-Muslim.

3. Friederike Trotier, Strengthening the Muslim Community in Indonesia and Beyond: The 2013 Islamic Solidarity Games in Palembang.

4. Ali Munhanif, Al-Shawkah al-Siyāsīyah li al-Afkār al-Dīnīyah: AlHarakah al-Tajdīdīyah al-Islāmīyah wa al-țaìq ilá Nuqtat Iltiqua alIsläm wa al-Dawlah.

5. Dadi Darmadi, Al-Islām wa al-Malāyū wa al-Siyādah fì al-Muhịt: Sultanat Brunei wa al-Isti mār Eropa fï Borneo.

6. Jajat Burhanudin, Islam dan Kolonialisme: Sayyid Usman dan Islam di Indonesia Masa Penjajahan. 


\section{Volume 22, Number 2, 2015}

1. Yuki Shiozaki, The Historical Origins of Control over Deviant Groups in Malaysia: Official Fatwa and Regulation of Interpretation.

2. Yanwar Pribadi, The Suramadu Bridge Affair: Un-bridging the State and the Kyai in New Order Madura.

3. Mikihiro Moriyama, Poet in an Islamic Community: Cultural and Social Activities of Acep Zamzam Noor in Tasikmalaya, West Java.

4. Jajang A. Rohmana, Al-Qur'ān wa al-Istímār: Radd al-Shaykh alHājj Ahmad Sanusi (1888-1950) 'alá al-Istímār min Khiläl Tafsīr Mal'ja' al-Tạlibin.

5. Mahrus As'ad, Tajdìd al-Tarbìyah al-Islämìyah 'inda al-Shaykh alHājj Imam Zarkasyi.

6. Suryadi, Isra Mikraj dalam Naskah-Naskah Indonesia.

\section{Volume 22, Number 3, 2015}

1. Anthony Reid, Religious Pluralism or Conformity in Southeast Asia's Cultural Legacy.

2. Asep Saepudin Jahar, Marketing Islam through Zakat Institutions in Indonesia.

3. Ayang Utriza Yakin, The Register of the Qadi Court "Kiyahi Pěqih Najmuddin " of the Sultanate of Banten, 1754-1756 CE.

4. Yahya Mohamed Ahmed Ghaleb, Ishkālìyāt al-Intimä̀ al-Wațan̄ inda al-Muhājirìn al-Hadārimah fì Indūnīsīyā fì al-Nisf al-Awwal min al-Qarn al-'Ishrīn.

5. Aan Hasanah, Al-Qiyam al-Thaqāfìyah wa Täbi“ al-Sha'b li Jayl alMuslimin al-Shubbān al-Indūnìsìyin.

6. Testriono, Islam Indonesia dan Demokratisasi: Dari Transisi ke Konsolidasi. 


\section{Guidelines}

\section{Submission of Articles}

tudia Islamika, published three times a year since 1994, is a bilingual (English and Arabic), peer-reviewed journal, and specializes in Indonesian Islamic studies in particular and Southeast Asian Islamic studies in general. The aim is to provide readers with a better understanding of Indonesia and Southeast Asia's Muslim history and present developments through the publication of articles, research reports, and book reviews.

The journal invites scholars and experts working in all disciplines in the humanities and social sciences pertaining to Islam or Muslim societies. Articles should be original, research-based, unpublished and not under review for possible publication in other journals. All submitted papers are subject to review of the editors, editorial board, and blind reviewers. Submissions that violate our guidelines on formatting or length will be rejected without review.

Articles should be written in American English between approximately 10.000-15.000 words including text, all tables and figures, notes, references, and appendices intended for publication. All submission must include 150 words abstract and 5 keywords. Quotations, passages, and words in local or foreign languages should 
be translated into English. Studia Islamika accepts only electronic submissions. All manuscripts should be sent in word to: studia. islamika@uinjkt.ac.id.

All notes must appear in the text as citations. A citation usually requires only the last name of the author(s), year of publication, and (sometimes) page numbers. For example: (Hefner, 2009a: 45; Geertz, 1966: 114). Explanatory footnotes may be included but should not be used for simple citations. All works cited must appear in the reference list at the end of the article. In matter of bibliographical style, Studia Islamika follows the American political science association (APSA) manual style, such as below:

1. Hefner, Robert, 2009a. "Introduction: The Political Cultures of Islamic Education in Southeast Asia," in Making Modern Muslims: The Politics of Islamic Education in Southeast Asia, ed. Robert Hefner, Honolulu: University of Hawai'i Press.

2. Booth, Anne. 1988. "Living Standards and the Distribution of Income in Colonial Indonesia: A Review of the Evidence." Journal of Southeast Asian Studies 19(2): 310-34.

3. Feener, Michael R., and Mark E. Cammack, eds. 2007. Islamic Law in Contemporary Indonesia: Ideas and Institutions. Cambridge: Islamic Legal Studies Program.

4. Wahid, Din, 2014. Nurturing Salafi Manhaj: A Study of Salafi Pesantrens in Contemporary Indonesia. PhD dissertation. Utrecht University.

5. Utriza, Ayang, 2008. "Mencari Model Kerukunan Antaragama." Kompas. March 19: 59.

6. Ms. Undhang-Undhang Banten, L.Or.5598, Leiden University.

7. Interview with K.H. Sahal Mahfudz, Kajen, Pati, June $11^{\text {th }}$, 2007.

Arabic romanization should be written as follows:

Letters: ', $b, t, t h, j, h, k h, d, d h, r, z, s, s h, s, d, t, z, ', g h, f, q, l$, $m, n, h, w, y$. Short vowels: $a, i, u$. long vowels: $\overline{\mathrm{a}}, \overline{\mathrm{i}}, \overline{\mathrm{u}}$. Diphthongs: aw, ay. Tà marbüttă: $t$. Article: al-. For detail information on Arabic Romanization, please refer the transliteration system of the Library of Congress (LC) Guidelines. 
ستو ديا إسلاميكا (ISSN 0215-0492; E-ISSN: 2355-6145) بحلة علمية دولية محكمة تصدر عن مركز دراسات الإسلام والمجتمع (PPIM) بجامعة شريف هداية الله الإسلامية الحكومية بجاكرتا، تعنى بدراسة الإسلام في إندونيسيا خاصة وفي جنوب شرقي آسيا عامة. وتستهدف المجلة نشر البحوث العلمية الأصيلة والقضايا المعاصرة حول الموضوع، كما ترحب بإسهامات الباحثين أصحاب التخصصات ذات الصلة. وتخضع جميع الأبحاث المقدمة للمجلة للتحكيم من قبل للجنة مختصة. تم اعتماد ستوديا إسلاميكا من قبل وزارة التعليم والثقافة بجمهورية إندو نيسيا باعتبارها دورية علمية (قرار المدير العام للتعليم العالي رقم: 56/DIKTI/Kep/2012).

ستو ديا إسلاميكا عضو في CrossRef (الإحالات الثابتة في الأدبيات الأكاديمية) منذ ع ا ـ ب، و بالتالي فإن جميع المقالات التي نشرقا مرقمة حسب معرّف الوثيقة الرقمية (DOI) ـ ستو ديا إسلاميكا بحلة مفهرسة في سكوبس (Scopus) منذ . ب مايو 0 • r.

\author{
حقوق الطبعة محفوظة
}

عنوان المر اسلة:

Editorial Office:

STUDIA ISLAMIKA, Gedung Pusat Pengkajian

Islam dan Masyarakat (PPIM) UIN Jakarta,

Jl. Kertamukti No. 5, Pisangan Barat, Cirendeu,

Ciputat 15419, Jakarta, Indonesia.

Phone: (62-21) 7423543, 7499272, Fax: (62-21) 7408633;

E-mail: studia.islamika@uinjkt.ac.id

Website: http://journal.uinjkt.ac.id/index.php/studia-islamika

$$
\begin{aligned}
& \text { قيمة الاشتر اك السنوي خارج إندونيسيا: }
\end{aligned}
$$

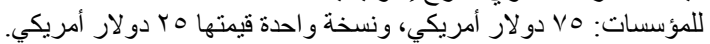

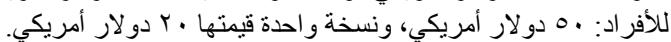

$$
\begin{aligned}
& \text { والقيمة لا تثمل نفقة الإرسال بالبريد الجوية والبي. } \\
& \text { رقم الحساب: - مابر }
\end{aligned}
$$

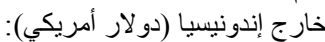

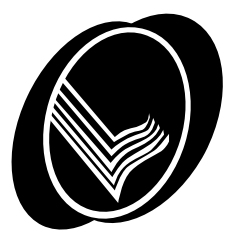




\section{ستوديا إسلاميكا}

مجلة إندو نيسيا للار اسات الإسلامية

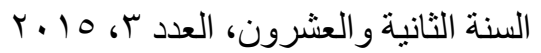

$$
\begin{aligned}
& \text { رئيس التحرير: } \\
& \text { أزيوماردي أزرا } \\
& \text { مدير التحرير: } \\
& \text { آيانج أوتريزا يقين } \\
& \text { هيئة التحرير : } \\
& \text { سيف المزاني } \\
& \text { جمهاري } \\
& \text { جاجات برهان الدين } \\
& \text { أومان فتح الرممن الدين }
\end{aligned}
$$

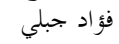

$$
\begin{aligned}
& \text { علي منحنف } \\
& \text { سيف الأمم } \\
& \text { إسماتو رافي } \\
& \text { دادي دارمادي } \\
& \text { ديدين شفر الدين } \\
& \text { جاجانج جهراني } \\
& \text { دين واحد }
\end{aligned}
$$

مجلس التحرير الدولي:

تعمد قريش شهاب (جامعة شريف هداية الله الإسلامية الحكومية بجاكر تا) توفيق عبد اللة (المركز الإندونيسي للعلوم) نور أ. فاضل لوبيس (الجامعة الإسلامية الحكومية سومطرة الشمالية) م. ش. ش. ريكليف (جامعة أستراليا الحكومية كانبيرا) مارتين فان برونيسين (جامعة أثريخة)

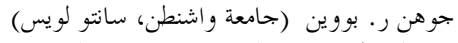

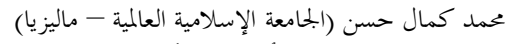

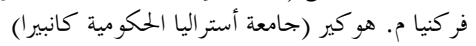
إيدوين ف. ويربخا (جامعة كولونيا، ألمانيا)

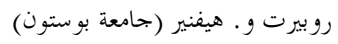
ريكي مادينير (المركز القومي للبحث العلمي بفرنسا)

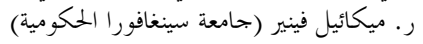
ميكائيل ف. لفان (جامعة فرينشتون)

مساعد هيئة التحرير: تيستر يونو محمد نداء فضلان

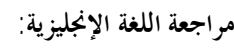
شيرلي باكير الخيلزية سيمون غلدمان - مان

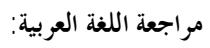
توباغوس أدي أسناوي 



\section{لالقوديا السل||مسيا}



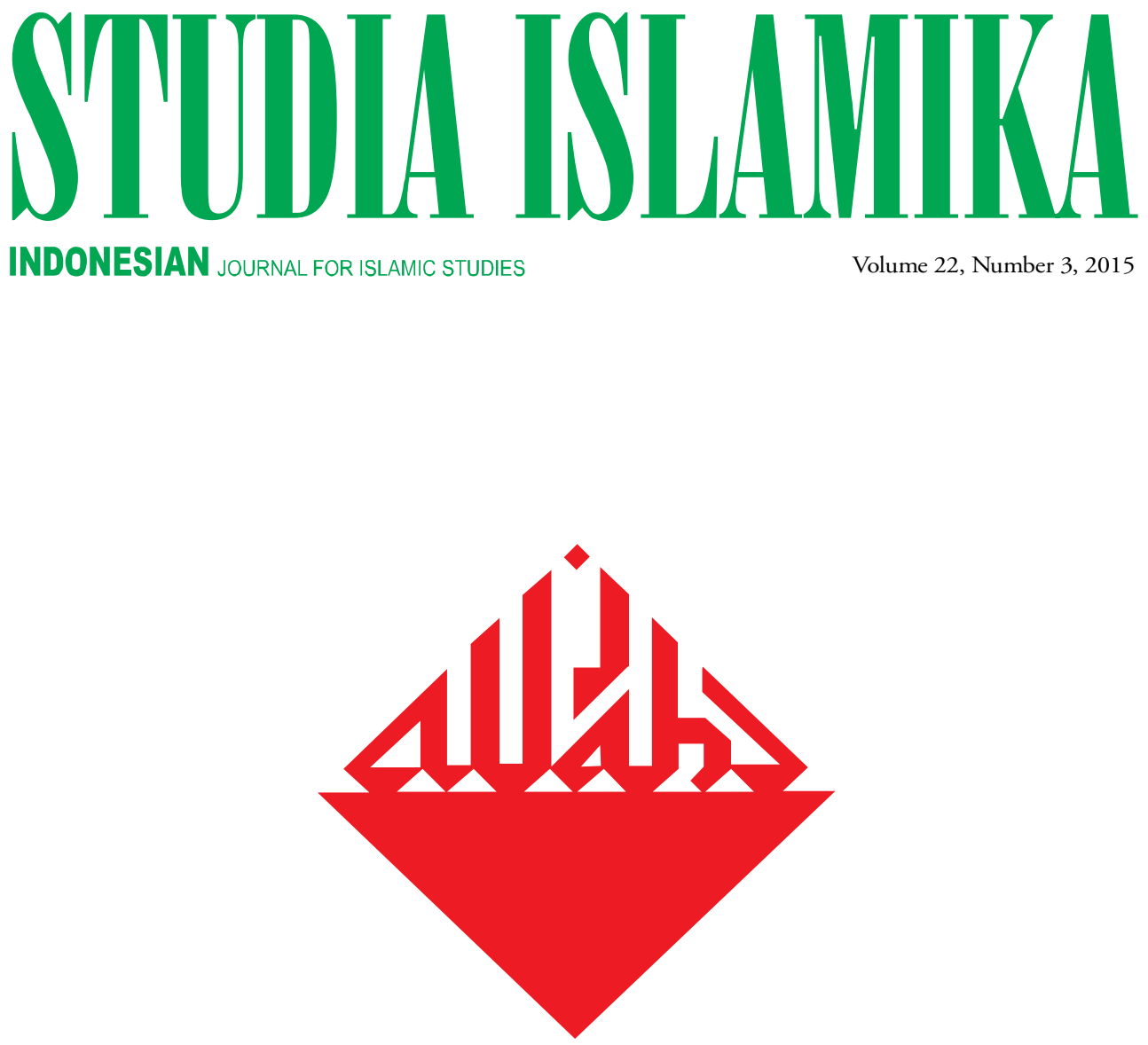

Religious Pluralism or Conformity in Southeast Asia’s Cultural Legacy

Anthony Reid

Marketing IsLam

THROUGH ZAKaT INSTITUTIONS IN INDONESIA

Asep Saepudin Jahar

The Register of the Qadi Court

“KiYahi PËQIh Najmuddin" of the Sultanate

of BANTĚN, I754-I756 CE.

Ayang Utriza Yakin 